\title{
Burnout Syndrome Among Intensive Care Nurses
}

\author{
Dejan B. Živanović ${ }^{1}$, Jovan M. Javorac ${ }^{2}$, Jasmina D. Knežević́ \\ ${ }^{1}$ College of vocational studies for education of preschool teachers and sport trainers, Depart- \\ ment of biomedical sciences, Subotica, Serbia \\ ${ }^{2}$ Institute of pulmonary diseases of Vojvodina, Sremska Kamenica, Serbia \\ ${ }^{3}$ College of vocational studies for education of preschool teachers and sport trainers, Depart- \\ ment of social and humanistic sciences, Subotica, Serbia
}

\section{SUMMARY}

Introduction: Professional burnout is a complicated state of mental, emotional and physical exhaustion, which mainly occurs among participants of so-called "helping professions". Regardless that intensive care units (ICU) have been recognized as one of the most stressful working environment in contemporary nursing, the burnout syndrome in the nursing profession is still under-investigated and neglected academic term in the scientific literature of Serbia and the surrounding countries.

Aim: The aim of this study was to assess the incidence of professional burnout among the intensive care unit (ICU) nurses, by using the inventory based on Freudenberger Burnout Scale.

Subjects and methods: This cross-sectional study included 71 nurses who were employed in intensive care units of surgery, urology, internal medicine, pediatrics, gynecology, obstetrics, and otorhinolaryngology departments in University Hospital Center "Dr. Dragiša Mišović", which is one of five University hospitals in Belgrade, Serbia, in July of 2017.

Results: The statistical analysis of the data obtained in this study showed alarming results-burnout syndrome affected approximately one-third of the observed subjects, in form of manifested or severe job burnout. In the same time, another third of subjects were classified in the category of burnout candidates.

Conclusions: Burnout incidence in observed sample exceeds the mean incidence of job burnout among nurses in other European countries that has been reported in the literature. Notwithstanding some limitations of this study (non-standardized questionnaire that was used in this study and relatively small sample of study participants from only one health care institution), the authors strongly believe that the obtained results clearly indicate necessity of further research into the problem of burnout in the nursing profession.

Keywords: ICU nurse, job burnout, risk factors 


\section{INTRODUCTION}

Contemporary nursing is considered one of the most stressful jobs requiring a simultaneous mental, physical and emotional engagement. As expected, the exposure of nurses to occupational stressors is most significant in intensive care units (ICU). Nowadays, ICU has been recognized as one of the most stressful working environment in global human professional activity, particularly for nurses, who are in close contact with hospitalized patients throughout all of their working hours [1,2]. The complexity of the job requirements and responsibilities, exceedingly great superiors' expectations regarding the working efficien$\mathrm{cy}$, overtime work, frequent working shifts, and above all, a usual lack of adequate public acknowledgments and awards for invested professional efforts, make the solid base for the development of professional exhaustion among ICU nurses [3,4]. Notwithstanding this, the burnout syndrome in the nursing profession is still under-investigated and neglected academic term in the scientific literature of Serbia and the surrounding countries.

The professional burnout is a complicated condition of mental, emotional and physical exhaustion, basically induced by long term exposure to high-intensity stress at work [5]. Substantially, this psycho-emotional construct is always due to "a serious discrepancy between the nature of a job and the nature of a person performing it" [6]. American psychologist Herbert Freudenberger was the first scientist who recognized this syndrome in 1974, defining it as "a breakdown of the psychological defense the employees use to adapt to and cope with the job-induced intense stress" $[7,8]$. Freudenberger designed the first applicable concept and professional burnout scale which became the basis of a variety of questionnaires assessing exposure to this syndrome. Even nowadays, a number of authors consider these questionnaires as reliable instruments to evaluate the risk and incidence of burnout in helping professions $[9,10]$.

The most frequently cited and most widely accepted definition of burnout syndrome describes this condition as a complex construct which includes three dimensions: emotional exhaustion (the stress component of burnout, characterized with a permanent "depletion" of an individual's emotional resources), depersonalization (the interpersonal component of burnout, manifested by the feeling of estrangement, alienation from other staff members, with a prominent cynical attitude in communication), and a diminished personal accomplishment (a self-evaluation component of burnout, characterized by a negative evaluation of personal professional competences, efficacy and accomplishment; this burnout dimension is also considered as most dangerous, because it may induce the depressive syndrome in a professionally exhausted person[11,12]. Synergic effects of individual and contextual job burnout-inducing factors lead to the development of the first noticeable manifestation of professional exhaustion: a person admitted to work with great enthusiasm, professional agility and a feeling of satisfaction, begins to experience the same job as unpleasant, exhausting, frustrating and traumatic. An employee's initial work energy gradually turns into exhaustion, efficiency into inefficiency, and devotion transforms into a strong cynicism, which becomes a habitual mode of behavior of a person affected by the burnout syndrome $[4,11]$.

The major stressful characteristics of the ICU nurse job include a high level of professional responsibility, and, even more, permanent exposure to the numerous emotional, mental and physical risk factors. Although it cannot be denied that personality traits play a crucial role in providing conditions for the development of burnout, intensive care units range among the workplaces with the greatest possible participation of contextual factors in burnout of the staff. All these contextual factors may become primary causes not only of anxiety and burnout syndrome but also of serious depression forms and posttraumatic stress disorders in extreme cases $[3,13]$. Participation in numerous delicate interventions that directly affect patients' life and death, as well as daily facing with their enormous physical and mental suffering, are considered topintensity occupational stressors in healthcare professions [1,14]. In addition, some burnout studies confirmed that frequent exposure of ICU nurses to moral distress, making them feel insufficiently efficient in their work with patients, is significantly related to the subjective experience of emotional exhaustion, which is the major component of job burnout. It should be also considered that daily ethical 
dilemmas related to the nursing care of seriously ill and dying patients affect nursing staff as well, both on the intellectual and emotional level $[15,16]$. Besides that, a high degree of immediate responsibility for patients' life and health, accompanied with an objectively low degree of independence in making professional decisions, represent an exceptionally important factor for the development of burnout in ICU $[9,17]$.

It should be emphasized that job burnout in healthcare professionals is always associated with an obvious work performance reduction, which finally results in a reduced quality of performed health care services [18]. In the ICU nursing profession, a nurse's reduced efficiency and personal engagement at work inevitably become noticed by the rest of the unit staff. Professional error rate increases, and at that point the burnout is no longer only a problem of the affected ones, but can seriously endanger the life of hospitalized patients $[3,19]$. Finally, a nurse who has been treating and taking care of patients until recently turns into a person who desperately needs professional help herself.

\section{AIM}

The aim of this non-commercial research, designed as a cross-sectional study, was to assess the incidence of professional burnout among ICU nurses in the observed sample, by using the inventory based on Freudenberger Burnout Scale.

\section{SUBJECTS AND METHODS}

We analyzed the data obtained from the 71 subjects who met the study inclusion criterion, requiring that the subject spent at least six consecutive months working in the intensive care unit - the minimum reported period for manifestation of burnout. Our study included the nursing staff of surgery, urology, internal medicine, pediatrics, gynecology, obstetrics, and otorhinolaryngology intensive care units, in University Hospital Center "Dr. Dragiša Mišović", one of five university hospital centers in Belgrade, Serbia, in July of 2017.

The research instrument was a questionnaire, uniquely designed for this study, consisting of two sections. The first section was intended for collecting sociodemographic information which is relevant for the develop- ment of burnout, including the participants' gender, age, education level, and type of work engagement (temporary or permanent), shift work inclusion, potential extra work engagement, marital status and accomplishment in parenting. The second part of questionnaire was the Burnout Survey in Croatian language $[20,21]$, based on the Freudenberger Burnout Scale, which was used as a research instrument in several graduate and master thesis at faculties in Croatia [4,21], originally developed for a similar research on job burnout that was conducted within the Croatian Society of Family Physicians (author's permission available) [22]. Considering the similarity between the Croatian and Serbian languages, the Ethical committees concluded that the questionnaire does not contain any words that respondents in Serbia would not be able to understand, and approved its use by an available written decision. In order to provide assistance in understanding questions in the survey, the examiner was always present when respondents in small groups were completing the questionnaire. The burnout questionnaire contains a total of 15 statements that describe possible manifestations of job burnout. Participants should assess presence/frequency and severity of those manifestations by choosing one of the offered answers on Likert scale, as 1 (never), 2 (rarely), 3 (sometimes), 4 (often) and 5 (always); the number preceding the answer, expresses the allotted score for a particular answer. The total score was interpreted as follows:

- 15 - 25 score - a participant is not at the risk of job burnout;

- 26 - 35 score - a participant is at the risk of job burnout;

- 36 - 50 score - a participant is a candidate for the job burnout;

- 51 - 65 score - a participant has a manifested burnout syndrome and

- 66 - 75 score - a participant has a prominent burnout syndrome ("has burnt out").

Results were statistically analyzed by using the SPSS Statistical Package for Windows, Version 16. The obtained results are presented in tables in form of descriptive statistics, including absolute and relative numbers, calculated mean values - the arithmetical mean, the median, as well as the variability measures - standard deviation (SD), and coefficient of variation $(\mathrm{CV})$. The difference between expected and observed respondent frequencies in relation to the presence and form of job 
burnout has been determined by using the Chi-square $\left(\mathrm{x}^{2}\right)$ independence test for one sample. The minimum significance level in this study was set to 0.05 .

\section{Limitations of the study}

The limitation refers to a non-standardized questionnaire that was used in this study, as well as a relatively small sample of study participants from only one health care institution. Notwithstanding the mentioned limitations, the authors of this study believe that the obtained results clearly indicate the necessity of further research into the problem of burnout in the nursing profession. In order to reach scientifically more significant results, prospective research on a larger sample of participants, from several health care institutions, should be considered.

\section{Ethical considerations}

Purpose, ethics, scientific basis and other rel- evant issues related to the conduction of this study have been considered and approved both by the ethical committees of the Faculty of Medicine, University of Novi Sad, and University Hospital Center "Dr. Dragiša Mišović" in Belgrade, documented by an available written decision. All participants have been included in the study on a voluntary basis exclusively. Information obtained from participants was appropriately treated as a professional secret. Each participant was informed about the aim of the study in the questionnaire preamble.

\section{RESULTS}

In the observed sample, differences have been registered in the subjects' gender distribution - 23 males (32.4\%), and 48 females (67.6\%). The mean age of the study participants was 33.8 years, with a slightly younger mean age of males - approximately 31.3 years (SD, 5.9; $\mathrm{CV}<30 \%)$, as compared to the mean females' age - approximately 36.3 years (SD, 9.5; $\mathrm{CV}<30 \%)$. Sex and age distribution of the ob-

\begin{tabular}{|l|c|c|c|c|c|c|c|c|}
\hline & & & & \multicolumn{7}{|c|}{ AGE } \\
\cline { 5 - 9 } \multicolumn{1}{c|}{ SEX } & $\mathrm{n}$ & $\%$ & $\overline{\mathrm{x}}$ & $\mathrm{SD}$ & $\mathrm{CV} \%$ & Med & Min. & Max. \\
\hline male & 23 & 32.4 & 31.3 & 5.9 & 18.8 & 31 & 22 & 43 \\
\hline female & 48 & 67.6 & 36.3 & 9.5 & 26.2 & 34 & 20 & 53 \\
\hline$\Sigma$ & 71 & 100.0 & 33.8 & & & & &
\end{tabular}

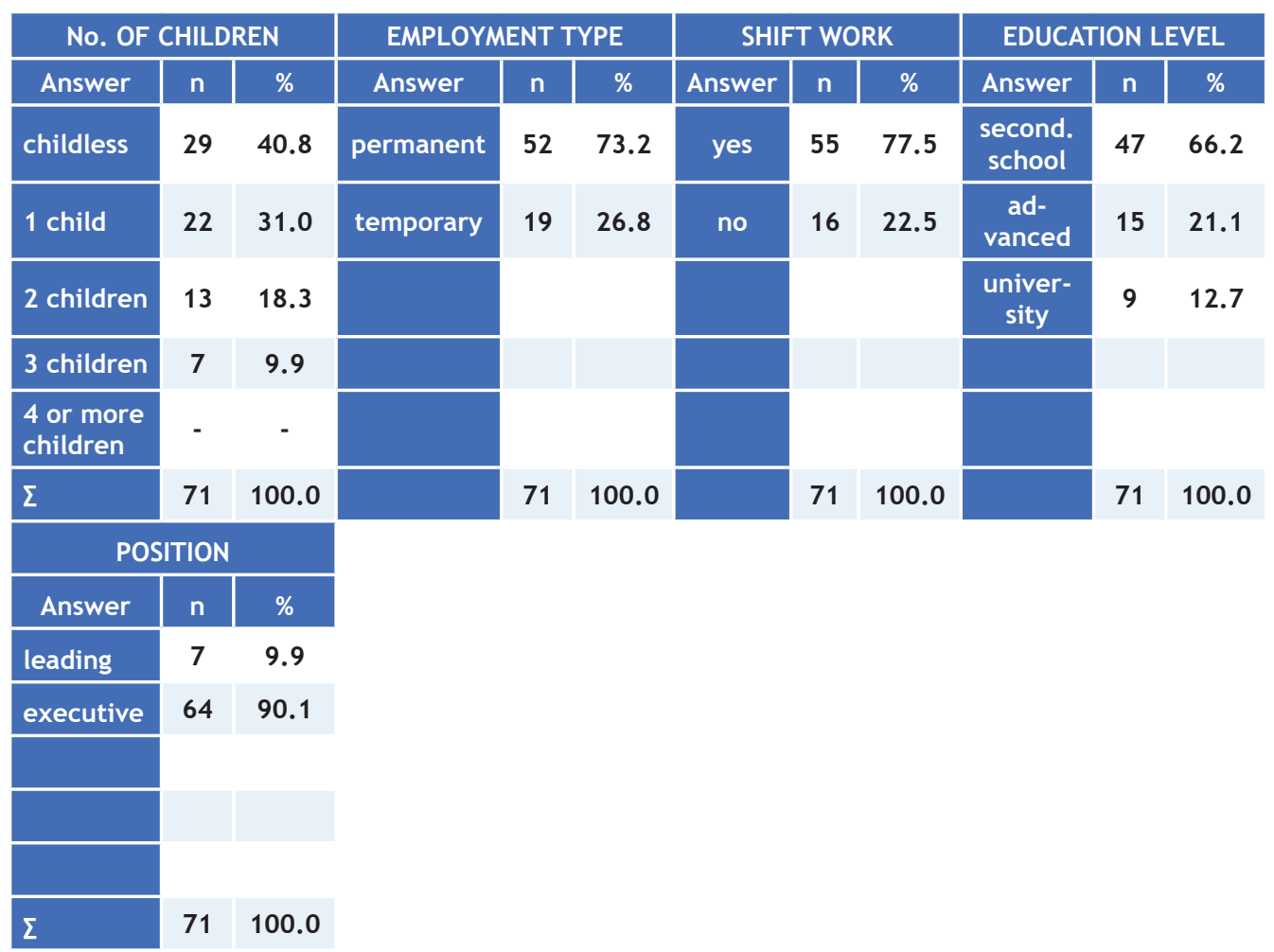

Table 1. Participants' sex and age distribution

Table 2. Participants' distribution depending on specific sociodemographic parameters 
served subjects are presented in Table 1.

Distribution of the examined subjects on the criteria of the specific sociodemographic parameters which may contribute to the occurrence of burnout, such as number of children, work engagement type, shift work, education level, and job type are presented in Table 2.

The majority of the participants, 29 in total, were not accomplished as parents (40.8\%); 22 of them had one child (31.0\%), 13 reported having two children (18.3\%), seven subjects had three children (9.9\%), while none of the subjects had four or more children. Concerning the subjects' distribution by the criterion of the work engagement type, 52 subjects $(73.2 \%)$ were permanently employed in the recent institution, and 19 subjects (26.8\%) had a temporary job replacing an absent employee, or due to the current extra employee requirement of the institution. Shift work involved 55 subjects in total (77.5\%). The further analysis has also established the predominance of the subjects with secondary school education level - 47 subjects (66.2\%); higher education had 15 subjects $(21.1 \%)$, and only nine subjects (12.7\%) had a university education in nursing science. Of the total number of the study participants, only seven (9.9\%) occupied the leading position (head nurse), and the rest 64 subjects $(90.1 \%)$ were direct nursing intervention executors (ward nurses).

By scoring and statistically analyzing responses obtained from the second part of the questionnaire, a statistically significant distribution of the study participants was established with the job burnout presence in the observed population $(\mathrm{p}<0.05)$. The burnout syndrome affected 24 subjects (33.8\%), exhibiting the following distribution: manifested burnout was registered in 17 , i.e. $23.9 \%$ subjects (SD, 3.4; $\mathrm{CV}<30 \%$ ), while seven subjects, or $9.9 \%$, were classified into the severe burnout category - "burnt out" (SD, 2.1; CV $<30 \%$ ). The category of burnout candidates included

Table 3. Distribution of the burnout syndrome (BOS) in the examined sample
$33.8 \%$ subjects (SD, $4.0 ; \mathrm{CV}<30 \%$ ); $21.1 \%$ of the subjects were at risk of job burnout (SD, 3.1 ; $\mathrm{CV}<30 \%$ ), and only $11.3 \%$ of the subjects $(\mathrm{SD}, 3.8 ; \mathrm{CV}<30 \%)$ were not at risk to develop the syndrome. Those results are shown in Table 3 .

\section{DISCUSSION}

Intensive care units (ICU) are specific organization entities of health care institutions where the most serious, critically ill patients are hospitalized [4]. Health conditions of these patients, often between life and death, unique job organization and nature of professional activities in these hospital units, management mode, as well as the way of interpersonal and interprofessional communication, significantly contribute to the creation of an exceptionally stressful working environment in ICU $[2,23,24]$. Long-term, permanent exposure to diverse professional stressors inevitably exhausts emotional and psychological capacities of the nurses working in ICU, thus making ideal conditions for the onset of emotional exhaustion, depersonalization, and feeling of reduced personal accomplishment [7,25].

This cross-sectional study included 71 ICU nurses. At the moment of entering the study, all participants were professionally engaged in one of the existing university hospital's intensive care units for at least six months continually, thus meeting a theoretical condition for developing job burnout $[4,26]$. Analyzing the examined subjects' sex structure, females have been found to prevail over males, which is not unusual for researches involving the nurse population [26]. Regardless of established statistical significance of subjects' distribution in our study, and gender relevance in job burnout development in some others [2729], the participants' gender was not considered as a predictor of a higher frequency of job burnout in the observed sample, since nursing and other helping professions are predomi-

\begin{tabular}{|l|c|c|c|c|c|c|c|c|}
\hline BOS $(\mathrm{x})$ & $\mathrm{n}$ & $\%$ & $\overline{\mathrm{x}}$ & $\mathrm{SD}$ & $\mathrm{CV} \%$ & Med & Min. & Max. \\
\hline No risk (15-25 b.) & 8 & 11.3 & 18.1 & 3.8 & 20.7 & 17 & 15 & 24 \\
\hline At risk (26-35 b.) & 15 & 21.1 & 29.8 & 3.1 & 10.5 & 29 & 26 & 35 \\
\hline Candidate $(36-50$ b.) & 24 & 33.8 & 44.4 & 4.0 & 9.0 & 44.5 & 37 & 50 \\
\hline Manifested (51-65 b.) & 17 & 23.9 & 55.7 & 3.4 & 6.2 & 54 & 52 & 62 \\
\hline Severe ("burnt out") (66-75 b.) & 7 & 9.9 & 67.9 & 2.1 & 3.1 & 67 & 66 & 71 \\
\hline$\Sigma$ & 71 & 100.00 & & & & & & \\
\hline P ( $\mathrm{x}^{2}$ test) & & & & \multicolumn{2}{|c|}{$<0.05$} & & &
\end{tabular}


nantly practiced by females. Further analysis of the obtained data shows that almost twothirds of participants were single (never married or divorced). In addition, statistically significant differences have been also registered regarding the parentage of examined subjects: more than two-fifths were childless. Almost all available and relevant job burnout studies report that this syndrome most frequently affects the population under 35 years of age (mean age of participants in this study was 33.8 years), single and childless, it may be easily concluded that significant number of the subjects included in our study were at serious risk of professional exhaustion due to their sociodemographic characteristics $[11,27,30]$.

Since the very beginning of researching the job burnout phenomenon, many scientists have been pointing out a shorter length of service as an important predictor for its development [31,32]. However, due to the inhomogeneity of the data in both groups of examined subjects, the obtained values due to length of service were not established to be statistically significant. Unlike the mentioned variable, a statistically significant predomination of participants involved in shift work has been established, amounting to more than three-quarters of examined subjects in total. Considering the results of a similar study carried out in other Serbian hospitals and some other affordable studies $[2,31,33,34]$. the shift work involvement can be also classified as a significant factor of job stress perception among participants in our study. Besides shift work, many scientists range the type of work engagement among significant situation factors for the development of burnout, pointing out a direct correlation of this factor with job certainty perception $[7,14,25]$. However, this kind of burnout risk couldn't be confirmed in our sample of ICU nurses, due to strong predomination of permanently employed study participants.

Specific for all healthcare professions, especially nursing, a significantly higher incidence of burnout was observed in person with lower level of formal education, particularly due to lack of chances for advancing in the career, as well as to frustrations induced by relationships and communication with superiors and their requirements from the employee $[4,25,35]$. In our study, a high and statistically significant participation of subjects with secondary level education has been registered, amounting to two-thirds subjects in total. Despite the obtained results, greater exposure of medical professionals with secondary level education to occupational stress should be carefully considered in the Serbian health care system, since there are significant differences compared to other European countries. In other words, due to existing disharmony between the nurse education system and healthcare job systematization, Serbian nurses with a high level education are often exposed to additional professional stress, because they can hardly obtain any kind of professional satisfaction for their efforts to acquire formal education $[9,36]$. The current situation in Serbian nursing, with characteristically high responsibility level and, practically, no space for making independent decisions, may over time become a cause of double role conflict and burnout, especially among university-educated nurses working on such demanding jobs, such as ICU.

Paradoxically, despite the certainty of all mentioned predictors, in practice, burnout is still most often unrecognized even in countries with developed programs for its prevention, not only in the nursing profession, but also in the global human occupational environment. Burnout syndrome is unevenly-distributed throughout the world, ranging from $20 \%$ in the USA, to $69 \%$ in Japan. It is still impossible to comprehensively determine the frequency of this syndrome in Europe; in the EU countries, job burnout affects up to $28 \%$ of the population, while this phenomenon has been scarcely investigated in East European countries [28]. In Croatian study on burnout among palliative care nurses, it was found that professional burnout affects about $25 \%$ of the examined subjects, which was considered alarming by the authors of the study [1]. According to authors of this and other similar studies, the reason why burnout should rise awareness is also the fact that consequences of job burnout in ICU and similar departments have an additional potentially dangerous aspect - effects of burnout inevitably affect the ICU patients as well, since this condition significantly reduces work motivation and professional efficacy of nurses $[25,36,37]$. Finally, the analysis of the data obtained in our research provided even more worrying results; a statistically significant subjects' distribution regarding the presence of the burnout syndrome has been established in the observed sample of ICU nurses: in form of manifested or severe job burnout, 
this phenomenon affected approximately onethird of the examined subjects, with another one-third who were classified in the category of burnout candidates. High exposure to objective risk of professional burnout has been registered even among the significant number of participants who were not affected at the moment of conducting this study; at the same time, the absence of predictors and job burnout manifestations was found in an extremely small number of the observed subjects.

\section{CONCLUSION}

The results of this cross-sectional study showed that the incidence of job burnout in the observed sample exceeds the mean incidence of job burnout among ICU nurses in other European countries that have been reported in the literature: burnout syndrome affected over one third of study participants; over two thirds of them developed the signs of the manifested burnout, while the rest had a severe burnout syndrome ("burnt out"). In addition, another third of study participants were classified into the category of burnout candidates at the same time, and an additional one-fifth has been found to be at serious risk for the development of this psycho-emotional phenomenon. Although this study included intensive care nurses from only one institution, the results clearly indicate the need for further researches, in order to determine efficient and sustainable activities of burnout prevention.

\section{CONFLICTS OF INTEREST}

All authors declare no conflict of interest.

\section{REFERENCES}

1. Novak V. Burnout syndrome among medical professionals working with terminally ill patients (article in Croatian with an abstract in English). Sestrinski glasnik/Nursing Journal. 2014;19:189-95.

2. Poncet MC, Toullic P, Papazian L, Kentish Barnes N, Timsit JF, Pochard F, Chevret S, Schlemmer B, Azoulay E. Burnout syndrome in critical care nursing staff. Am J Respir Crit Care Med. 2007;175(7):698704.

3. Moss M, Good VS, Gozal D, Kleinpell R, Sessler $\mathrm{CN}$. A critical care societies collaborative statement: Burnout syndrome in critical care healthcare professionals. A call for action. Am J Respir Crit Care Med. 2016;194(1):106-13.

4. Buljubašić A. Sindrom sagorijevanja među zdravstvenim djelatnicima [Master thesis/Croatian]. Split (CRO): University of Split, Dept. of health sciences; 2015.

5. Cvetković S. Sindrom sagorevanja, psihosomatsko reagovanje, motivacija za postignućem i dimenzije ličnosti kod zaposlenih na rukovodećim i nerukovodećim radnim mestima [PhD thesis/Serbian]. Niš (SER): University of Niš, Faculty of philosophy; 2016.

6. Maslach C. Burned - out. Human behavior. 1976;9(5):16-22.

7. Ivković J. Burnout syndrome and impact on our life (article in Serbian with an abstract in English). Sestrinska reč. 2015;19(72):16-7.

8. Bukumirović AM, Totić-Poznanović SD, MarkovićDenić LJN, Bukumirić ZM, Vlačić AN, Radak VS, Lasica RM, Šijački AD. Burnout syndrome at work by doctors employed at Emergency center of Clinical center of Serbia. Hospital Pharmacology. 2018;5(2):647-53.

9. Jović $D$, Knežević $D$, Egeljić Mihailović N. Problems of graduate nurses in everyday practice (article in Serbian with an abstract in English). Sestrinski žurnal/Nursing Journal. 2015;2(2):5-10.

10. Demerouti E, Nachreiner F, Bakker A, Schaufeli $W$. The job demands - resources model of burnout. J App Psychol. 2001;86(3):499-512.

11. Popov S, LatovljevM, Nedić A. Sindrom izgaranja kod zdravstvenih i prosvetnih radnika: uloga situacionih $\mathrm{i}$ individualnih faktora (In Serbian). Psihološka istraživanja. 2015;18(1):5-22.

12. Popov B, Miljanović M, Stojaković M, Matanović $M$. Work stressors, distress and burnout: the role of coping strategies (article in Serbian with an abstract in English). Primenjena psihologija. 2013;6:355-70.

13. Vahedian Azimi A Hajiesmaeili M, Kangasniemi $M$, Fornés-Vives J, Hunsucker RL, Rahimibashar F, Pourhoseingholi MA, Farrokhvar L, Miller AC. Effects of stress on critical care nurses: a national cross - sectional study. J Intensive care med. 2017; doi: $10.1177 / 0885066617696853$

14. Knežević B, Golubić R, Milošević M, Matec L, Mustajbegović J. Zdravstveni djelatnici u bolnicama i stres na radu: istraživanje u Zagrebu (In Croatian). Sigurnost. 2009;51(2):85-92.

15. Meltzer LS, Huckabay LM. Critical care nurses perceptions of futile care and its effects on burnout. Am J Crit Care. 2004;13(3):202-08.

16. Solomon MZ, O’Donell L, Jennings B, Guilfoy V, Wolf SM, Nolan K, Jackson R, Koch-Weser D, Donnelley $S$. Decisions near the end of life: professional views on life-sustaining treatments. Am J Public Health. 1993;83:14-23.

17. Epp K. Burnout in critical care nurses: a literature review. Dynamics. 2012;23(4):25-31. 
18. Vićentić $S$, Jovanović A, Dunjić B, Pavlović $Z$, Nenadović $M$, Nenadović N. Professional stress in general practitioners and psychiatrists - the level of psychologic distress and burnout risk (article in Serbian with an abstract in English). Vojnosant Pregl. 2010;67(9):741-46.

19. Ćirić Z, Živanović D, Stojaković N. Neželjeni događaji i pojam profesionalne greške u sestrinskoj praksi (In Serbian). Vizija. 2018;2(1):25-28.

20. Jakšić M. Sindrom izgaranja na radnome mjestu. Dakovo (CRO): Katolički bogoslovni fakultet; 2014.

21. Božinović R. Sindrom izgaranja kod liječnika opće/obiteljske medicine [Graduate thesis/Croatian]. Osijek (CRO): Josip Juraj Strossmayer University, Faculty of medicine; 2017.

22. Mazzi B, Ferlin D. Sindrom sagorjelosti na poslu - naš profesionalni problem. Zagreb: Hrvatski liječnički zbor - Hrvatsko društvo obiteljskih doktora; 2009.

23. Milutinović D, Golubović B, Brkić N, Prokeš B. Professional stress and health among critical care nurses in Serbia. Arh Hig Rada Toksikol. 2012;63:171-80.

24. Bakker AB, Le Blanc PM, Schaufeli WB. Burnout contagion among intensive care nurses. J Adv Nurs. 2005;51:276-87.

25. Vovra K. Preopterećenost medicinskih sestara na poslu [Graduate thesis/Croatian]. Zagreb (CRO): University of Zagreb, Faculty of medicine; 2015.

26. Čubrilo Turek M, Urek R, Turek S. Burnout syndrome - assessment of a stressful job among intensive care staff. Coll antropol. 2006;30(1):131-35.

27. Milutinović D, Grujić N, Jocić N. Identification and analysis of stress factors at nursing workplace: a comparative study of four clinical departments (article in Serbian with an abstract in English). Med Pregl. 2009;62(1/2):68-73.

28. Dedić G. Sindrom sagorevanja na radu (In Serbian). Vojnosanit Pregl. 2005; 62(11):851-55.

29. Popov B, Popov S. Polne razlike u doživljaju stresa na radu (In Serbian). Primenjena psihologija. 2011;4:179-95.

30. Demirci S, Yildirim YK, Ozsaran Z, Uslu R, Yalman $D$, Aras $A B$. Evaluation of burnout syndrome in oncology employees. Med Oncol. 2010;27:968-74.

31. Schaufeli WB. Burnout: a short socio - cultural history. In: Neckel S. Schaffner AK, Wagner G (editors). Burnout, fatigue, exhaustion. Springer international publishing; 2017. pp. 105-27.

32. Freudenberger HJ. Staff burnout. Journal of social issues. 1974;30:159-65.

33. Crepajac T. Uticaj smenskog rada medicinskih sestara na nivo stresa i umora [Master thesis/Serbian]. Novi Sad (SER): University of Novi Sad, Faculty of medicine; 2015.

34. Jovanović J. Modeli stresa na poslu. In: Jovanović J. Ergonomija i medicina rada. Banja Luka: Panevropski univerzitet “Apeiron”; 2009. pp. 61-114.

35. Maslach C. Understanding burnout: definitional issues in analyzing a complex phenomenon. In: Paine WS (editor). Job stress and burnout. Beverly Hills, CA: Sage; 1982; pp. 29-40.

36. Tikvić M. Usporedba organizacije sestrinske skrbi u Hrvatskoj i drugim zemljama Europske unije [Graduate thesis]. Zagreb (CRO): University of Zagreb, Faculty og medicine; 2014.

37. Kalauz S. Sindrom sagorijevanja na poslu medicinskih sestara. In: Anić B. (editor): Proceedings of the 7th Congress of Cardiac Society with International Participation (In Croatian); 16-18 October 2008; Opatija. Zagreb: Liječnički vjesnik - glasilo Hrvatskoga liječničkoga zbora; 2008. p. 120. 


\title{
Sindrom izgaranja kod medicinskih sestara zaposlenih u jedinicama intenzivne nege
}

\author{
Dejan B. Živanović1 Jovan M. Javorac², Jasmina D. Knežević \\ ${ }^{1}$ Visoka škola strukovnih studija za obrazovanje vaspitača i trenera, Katedra za biomedicinske nauke, \\ Subotica, Srbija \\ ${ }^{2}$ Institut za plućne bolesti Vojvodine, Sremska Kamenica, Srbija \\ ${ }^{3}$ Visoka škola strukovnih studija za obrazovanje vaspitača i trenera, Katedra za društvene i humanističke \\ nauke, Subotica, Srbija
}

\section{KRATAK SADRŽAJ}

Uvod: Profesionalno izgaranje predstavlja složeno stanje mentalne, emocionalne i fizičke iscrpljenosti koje se uglavnom javlja kod pripadnika tzv. "pomagačkih profesija". Uprkos tome što su jedinice intenzivne nege (JIN) prepoznate kao jedno od najstresnijih radnih okruženja u savremenom sestrinstvu, sindrom izgaranja u sestrinskoj profesiji je još uvek nedovoljno istražen i zapostavljen akademski pojam u naučnoj literaturi Srbije i okolnih zemalja u regionu.

Cilj: Cilj istraživanja je bio da se utvrdi zastupljenost profesionalnog izgaranja kod medicinskih sestara u jedinicama intenzivne nege, korišćenjem upitnika zasnovanog na Frojdenbergerovoj skali profesionalnog izgaranja.

Ispitanici i metode: $U$ ovoj studiji preseka je učestvovala ukupno 71 medicinskih sestara, zaposlenih u jedinicama intenzivne nege odeljenja za hirurgiju, urologiju, internu medicinu, pedijatriju, ginekologiju, akušerstvo i otorinolaringologiju $\mathrm{KBC}$ " $\mathrm{Dr}$ Dragiša Mišović”, jedne od pet univerzitetskih bolnica u Beogradu, Srbija, u julu 2017. godine.

Rezultati: Statistička obrada podataka dobijenih u ovoj studiji je pokazala alarmantne rezultate - profesionalnim izgaranjem je bila zahvaćena približno jedna trećina ispitanika, u formi manifestnog ili teškog sindroma izgaranja. Istovremeno, još jedna trećina ispitanika je svrstana u kategoriju kandidata za nastanak profesionalnog izgaranja.

Zaključak: Zastupljenost profesionalnog izgaranja u ispitivanom uzorku premašuje prosečnu učestalost sindroma izgaranja u drugim evropskim zemljama, opisanu u literaturi. Bez obzira na određena ograničenja studije (korišćenje nestandardizovanog upitnika i relativno mali uzorak ispitanika iz samo jedne zdravstvene ustanove), autori čvrsto veruju da dobijeni rezultati jasno ukazuju na nužnost sprovođenja daljih istraživanja o problemu sindroma izgaranja u profesiji sestrinstva.

Ključne reči: medicinska sestra JIN, profesionalno izgaranje, faktori rizika 